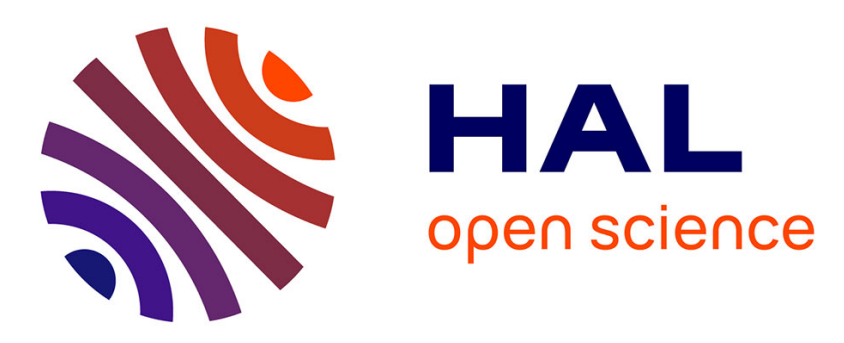

\title{
Plant functional trait effects on runoff to design herbaceous hedges for soil erosion control
}

Léa Kervroëdan, Romain Armand, Mathieu Saunier, Jean-François Ouvry, Michel-Pierre Faucon

\section{- To cite this version:}

Léa Kervroëdan, Romain Armand, Mathieu Saunier, Jean-François Ouvry, Michel-Pierre Faucon. Plant functional trait effects on runoff to design herbaceous hedges for soil erosion control. Ecological Engineering, 2018, 118, pp.143-151. 10.1016/j.ecoleng.2018.04.024 . hal-02365633

\section{HAL Id: hal-02365633 https://hal.science/hal-02365633}

Submitted on 15 Nov 2019

HAL is a multi-disciplinary open access archive for the deposit and dissemination of scientific research documents, whether they are published or not. The documents may come from teaching and research institutions in France or abroad, or from public or private research centers.
L'archive ouverte pluridisciplinaire HAL, est destinée au dépôt et à la diffusion de documents scientifiques de niveau recherche, publiés ou non, émanant des établissements d'enseignement et de recherche français ou étrangers, des laboratoires publics ou privés. 


\title{
ACCEPTED VERSION
}

\section{$1 \quad$ Plant functional trait effects on runoff to design herbaceous}

\section{hedges for soil erosion control}

4 5

\author{
Léa Kervroëdan ${ }^{*}$ ab , Romain Armand ${ }^{\text {a }}$, Mathieu Saunier ${ }^{\mathrm{b}}$, Jean-François \\ Ouvry $^{b}$, Michel-Pierre Faucon ${ }^{a}$ \\ a AGHYLE, UP.2018.C101, SFR Condorcet FR CNRS 3417, UniLaSalle, 19 Rue \\ Pierre Waguet, 60026 Beauvais, France \\ ${ }^{\mathrm{b}}$ AREAS, 2 avenue Foch, 76460 St Valéry en Caux, France \\ *Corresponding author: lea.kervroedan@unilasalle.fr
}

\begin{abstract}
Vegetation controls concentrated runoff and erosion in the European loess belt by increasing hydraulic roughness and sediment retention. Studies of plant effects on runoff velocity are usually based on a taxonomical characterisation and do not consider the effects of aboveground plant functional traits in attempts to understand soil erosion by water. This trait-based plant study investigates aboveground plant functional trait effects of herbaceous hedges on the hydraulic roughness to understand soil erosion. Eight aboveground functional traits were measured on fourteen indigenous and perennial plant species (caespitose or comprising dry biomass in winter) from north-west Europe with a high morphological variability. For each trait, density-weighted traits were calculated.
\end{abstract}


23 The effects of functional traits and density-weighted traits were examined using a runoff

24 simulator with four discharges. The leaf density and area, as well as density-weighted stem and leaf areas, stem diameter and specific leaf area were positively correlated with the hydraulic roughness. Generalised linear models defined the best combinations of traits and density-weighted traits: (1) leaf density and leaf area, (2) density-weighted leaf area and density-weighted projected stem area, and (3) density-weighted leaf area and densityweighted stem diameter. Moreover, the effects of leaf density, leaf area and densityweighted specific leaf area, varied depending on the discharge. This study is one of the first characterisation of aboveground trait effects on hydraulic roughness and highlights that vegetation with important stem density, diameter and leaf area plays a significant role in minimising soil erosion. The selection of plant species can derive from these plant trait effects to design reconstructed herbaceous hedges to minimise soil erosion.

\section{Key-words}

Aboveground functional traits; ecohydrological processes; hydraulic roughness; plantrunoff interaction; sediment retention; soil erosion control

\section{Introduction}

Soil erosion by water is influenced by precipitation, soil texture and structure, slopes that can generate intense discharges, and plant and litter covers which vary according to cultural practices in cultivated areas. Intense runoff and soil erosion are frequently found in north-western European catchments where the sloping loamy soils are intensively tilled and cultivated with annual crops (Boardman and Poesen, 2006; Gobin et al., 2003). In the European loess belt, erosion can be mitigated by both (1) tillage reduction and the 
establishment of cover crops during sensitive seasons which increase the crop residue quantity on soil surface and thus, reduce the rill and inter-rill soil erosion (Knapen et al., 2007), and (2) establishment of vegetative barriers across the thalweg to mitigate rill and ephemeral gully erosion (Richet et al., 2017). Richet et al. (2017) demontrated the effects of fascines (i.e. vegetative barriers made of bundles of stems) on hydraulic roughness and soil erosion mitigation however, their short lifetime and high cost represent a main limitation. Herbaceous hedges, defined as narrow strips of dense and stiff perennial vegetation, constitute a major interest to develop vegetative barriers with a high efficiency on the reduction of soil erosion at lower cost against concentrated flows (Dabney et al., 1995; Yuan et al., 2009). Besides, herbaceous hedges composed of indigenous plant species could offer other ecosystem services than regulating services such as the provision of habitats and their ecological connectivity in these catchments (Ouin and Burel, 2002; Smith et al., 2008).

The effect of herbaceous vegetation on runoff and soil erosion, have been studied over the past decades (Haan et al., 1994; Lambrechts et al., 2014; Ludwig et al., 2005; Temple et al., 1987). Blanco-Canqui et al. (2006), Dosskey et al. (2010), Lambrechts et al. (2014), Le Bissonnais et al. (2005), Ruiz-Colmenero et al. (2013) and Stokes et al. (2014) noted the direct effects of vegetation cover on splash detachment and inter-rill erosion reduction. The impact of plant roots on infiltration capacity and resistance of soils to erosion by water has been well documented (Berendse et al., 2015; Dabney et al., 2009; De Baets et al., 2006; De Baets and Poesen, 2010; Gyssels et al., 2005; Isselin-Nondedeu and Bédécarrats, 2007; Lambrechts et al., 2014). The influence of vegetation on sediment retention was highlighted (Burylo et al., 2012; Dabney et al., 2009; Dillaha et al., 1989; Haan et al., 1994; Isselin-Nondedeu and Bédécarrats, 2007; Lowrance et al., 1995). The 
relationship between vegetation and sediment retention can be understood only if the vegetation effect on hydraulic roughness, which is the frictional resistance due to the contact of runoff with the vegetation, is characterised, as it is the main process with gravity furthering sediment retention. This effect has been previously investigated (Akram et al., 2014; Cantalice et al., 2015; Cao et al., 2015; Haan et al., 1994; Järvelä, 2002; Temple et al., 1987). The presence of herbaceous vegetation has positive impacts on hydraulic roughness, as it reduces flow velocity and increases backwater depth (Akram et al., 2014; Cantalice et al., 2015; Hussein et al., 2007), thereby increasing sediment retention due to its linear relationship with backwater depth (Dabney et al., 1995; Hussein et al., 2007; Meyer et al., 1995). Plant effects on hydraulic roughness are highly variable among species and are difficult to explain without characterisation of all aboveground morphological traits (Cantalice et al., 2015; Cao et al., 2015; Dabney et al., 1995). The relationship between aboveground plant morphology and hydraulic roughness should be specified to globally understand runoff and soil erosion processes.

One of the challenges to improving the understanding in plant and vegetation (e.g. herbaceous hedges) effects on hydraulic roughness and soil erosion is the development of a functional trait-based approach (Faucon et al., 2017). This approach, which allows for characterising trait effects on ecosystem processes and services (Lavorel and Garnier, 2002), has been developed with the establishment of the relationship between the soil detachment ratio and root length density for underground biomass (De Baets and Poesen, 2010; Mekonnen et al., 2016; Vannoppen et al., 2015). Concerning aboveground characteristics, trait-based approaches highlighted the relationships between stem density, diameter and stiffness, and between leaf area and density with sediment retention (Bochet et al., 2000; Burylo et al., 2012; Mekonnen et al., 2016; Zhu et al., 2015). Because the 
hydraulic roughness is one of the main process influencing sediment retention, plant functional traits known to influence sediment retention could influence the hydraulic roughness. Those traits, such as the stem and tiller density (Hayes et al., 1978; IsselinNondedeu and Bédécarrats, 2007; Morgan and Duzant, 2008; Temple, 1982), stem diameter (Bochet et al., 2000; Meyer et al., 1995; Morgan and Duzant, 2008), stem stiffness (Dabney et al., 2009; Meyer et al., 1995), specific leaf area (Graff et al., 2005), leaf area (Burylo et al., 2012) and leaf density (Lambrechts et al., 2014), should be considered to specifically characterise the effect of aboveground traits on hydraulic roughness. In addition to characterising vegetation effects on hydrological processes and, notably, hydraulic roughness, the weight of traits in the vegetation should be considered (Garnier and Navas, 2012) to improve the overall understanding of soil erosion.

Plant functional trait effects on hydraulic roughness should vary according to water discharge and different hydraulic processes (Cao et al., 2015). Vieira and Dabney (2012) showed that flow resistance of vegetation changed with flow depth. Temple et al. (1987) and Van Dijk et al. (1996) found that for low flows, the mean flow velocity was dependent on the vegetation density. However, for higher flows, when the flow depth was higher than the deflecting vegetation height, the leaf structures had less impact and the flow resistance was primarily dependent on the stem density and length and on the stem diameter and stiffness (Meyer et al., 1995; Temple et al., 1987).

It is thus expected that high discharges would challenge the mechanical resistance through the stiffness, the density and the diameter of the stems, while low discharges would be impacted by the overall vegetation density. The challenge is to highlight plant functional trait effects on hydraulic roughness at several discharges that are representative of those present in catchments of north-west Europe. 
119 This study of trait-based plant ecohydrology examined the relationship between

120 aboveground plant functional traits with the hydraulic roughness at different discharges

121 in fourteen perennial plant species presenting contrasting aboveground functional traits.

122 The objectives are (1) to highlight the major functional traits influencing hydraulic

123 roughness and (2) to examine the effect of discharges on the relationship between plant

124 functional traits and hydraulic roughness to improve the understanding of soil erosion and

125 select candidate species to create reconstructed herbaceous ecosystems to mitigate soil 126 erosion in north-west Europe.

\section{Materials and methods}

\subsection{Plant materials}

130 Fourteen plant species that display contrasting aboveground morphological traits were

131 chosen from 76 candidate species, resulting in six filters of selected functional types

132 involved in mitigation of soil erosion in north-west Europe applied to the 3,500

133 spermatophyte species from north-west Europe (Lambinon et al., 2012). These selective

134 filters were as follows: (1) Raunkiaer's life-form categories of "herbaceous

135 chamaephytes", "hemicryptophytes" and "geophytes", i.e., perennial herbaceous

136 vegetation that provide an effective soil cover during all seasons; (2) the presence of fresh

137 (i.e., herbaceous chamaephytes and caespitose hemicryptophytes) or dry (i.e., non-

138 caespitose hemicryptophytes and geophytes) biomass in winter when soil erosion is

139 observed in north-west Europe (Boardman and Poesen, 2006); (3) the presence of

140 rhizomes or stolon to ensure lateral spreading capacity and burial tolerance due to

141 sediment deposition; (4) vegetative height $\geq 20 \mathrm{~cm}$, as it is the water maximal level in the

142 catchment in north-west Europe; (5) a broad ecological niche to select species able to 
143 grow in several silty agricultural soils; and (6) non-weed species to prohibit their

144 expansion in agricultural territories of north-west Europe.

145 Thirteen of the tested species were from the list of candidates (Carex sylvatica, Carex

146 flacca, Carex acutiformis, Carex pendula, Artemisia vulgaris, Origanum vulgare, Lolium

147 perene, Senecio jacobaea, Tanacetum vulgare, Festuca arundinacea, Dactylis glomerata,

148 Melica nutans, Phalaris arundinacea) (Table 1). An exotic species, Miscanthus sinensis,

149 was also tested along the thirteen indigenous species as it is considered a model plant in

150 studies of plant hydraulic properties and erosion mitigation (Dabney et al., 2009).These

151 species, varying in leaf and stem traits (e.g., density, area and specific area - density,

152 diameter, specific density and dry matter content), were chosen to establish a range of

153 traits to highlight the effect of aboveground plant traits on hydraulic roughness. The

154 species were collected in natura, selecting only established individuals, and planted in $15560 \times 30 \times 15 \mathrm{~cm}$ plots in early April 2016, creating 14 monospecific herbaceous hedges.

156 These vegetation plots consisted of a wooden frame with a $1.5 \mathrm{~cm}$ grid fence at the bottom

157 and were buried for three months prior the experiments to allow the full development of

158 the plants and roots. The plot design allowed for both plant growth and plot extraction for

159 the experiments in the runoff simulator. 
Table 1. List of the species used for the study and basic information.

\begin{tabular}{|c|c|c|c|c|}
\hline Category & Species name & Family & Life form & $\begin{array}{l}\text { Vegetative } \\
\text { height }(\mathrm{m})\end{array}$ \\
\hline \multirow{6}{*}{ Graminoid } & Dactylis glomerata $L$. & Poaceae & Hemicryptophyte & $0.96( \pm 0.11)$ \\
\hline & Festuca arundinacea Schreb. & Poaceae & Hemicryptophyte & $0.54( \pm 0.14)$ \\
\hline & Lolium perenne $L$. & Poaceae & Hemicryptophyte & $0.34( \pm 0.02)$ \\
\hline & Melica nutans $L$. & Poaceae & Hemicryptophyte & $0.28( \pm 0.02)$ \\
\hline & Miscanthus sinensis & Poaceae & Hemicryptophyte; Geophyte & $1.03( \pm 0.26)$ \\
\hline & Phalaris arundinacea $L$. & Poaceae & Hemicryptophyte & $0.49( \pm 0.11)$ \\
\hline \multirow{4}{*}{ Herb } & Artemisia vulgaris $L$. & Asteraceae & Hemicryptophyte & $0.96( \pm 0.17)$ \\
\hline & Origanum vulgare $L$. & Lamiaceae & Chamaephyte; Hemicryptophyte & $0.48( \pm 0.06)$ \\
\hline & Senecio jacobaea $L$. & Asteraceae & Hemicryptophyte & $0.98( \pm 0.04)$ \\
\hline & Tanacetum vulgare $L$. & Asteraceae & Hemicryptophyte & $0.64( \pm 0.07)$ \\
\hline \multirow{4}{*}{ Sedge } & Carex acutiformis Ehrh. & Cyperaceae & Hemicryptophyte & $0.17( \pm 0.03)$ \\
\hline & Carex flacca Schreb. & Cyperaceae & Hemicryptophyte & $0.31( \pm 0.04)$ \\
\hline & Carex pendula Huds. & Cyperaceae & Caespitose hemicryptophyte & $0.23( \pm 0.15)$ \\
\hline & Carex sylvatica Huds. & Cyperaceae & Caespitose hemicryptophyte & $0.12( \pm 0.03)$ \\
\hline
\end{tabular}

The stem height values represent the mean values ( \pm standard deviation) measured on the experimental plots. 
163 Eight aboveground plant morphological traits (leaf - area, density and specific area; stem

164 - density, diameter, specific density, area and dry matter content), potentially involved in 165 increasing hydraulic roughness, were measured (Table 2) at three levels along the stem 166 between 0 and $5 \mathrm{~cm}, 0$ and $10 \mathrm{~cm}$, and 0 and $20 \mathrm{~cm}$ - related to the variation of the water

167 flow depth. Sampling collection and process methods followed the guidelines from 168 (Pérez-Harguindeguy et al., 2013). The leaves and stems were wrapped in moist paper 169 and sealed in bags to limit water loss until the measures were complete, and they were 170 then dried at $70^{\circ} \mathrm{C}$ for $72 \mathrm{~h}$. 
171 Table 2. List of the measured traits, their abbreviations and formulas used.

\begin{tabular}{|c|c|c|c|c|}
\hline Morphological trait & Abbreviation & Unit & Formula $^{a}$ & $\begin{array}{c}\text { Abbreviation } \\
\text { after density- } \\
\text { weighting }\end{array}$ \\
\hline Stem density & SD & stems.dm ${ }^{-2}$ & - & - \\
\hline Leaf density & $\mathrm{LD}$ & leaves. $\mathrm{dm}^{-2}$ & - & - \\
\hline Leaf area & LA & $\mathrm{mm}^{2}$ & - & WLA \\
\hline Specific leaf area & SLA & $\mathrm{mm}^{2} \cdot \mathrm{mg}^{-1}$ & $S L A=L A(\text { Leaf massdry })^{-1}$ & WSLA \\
\hline Stem diameter & $\mathrm{SDm}$ & $\mathrm{mm}$ & - & WSDm \\
\hline Specific stem density & SSD & $\mathrm{mg} \cdot \mathrm{mm}^{-3}$ & $S S D=$ Massoven dry $(\text { Stem volume })^{-1}$ & WSSD \\
\hline Stem dry matter content & SDMC & - & SDMC $=$ Massoven dry $(\text { Massfresh })^{-1}$ & WSDMC \\
\hline Projected stem area & SA & $\mathrm{mm}^{2}$ & $S A=L S D m$ & WSA \\
\hline
\end{tabular}


173 Trait measurements were performed within two $10 \times 10 \mathrm{~cm}$ quadrats in each plot, to

174 ensure representative sampling. Stem density was measured within each quadrat, defining 175 pseudoculms in sedge species (Cyperaceae) and tillers in grass species as stems. Fresh

176 and dry leaves were counted to determine the leaf density at each level along the stems in 177 the quadrats. Specific leaf area (SLA) and leaf area were calculated from three mature 178 leaves per quadrat. The leaves were scanned while fresh using a 600 dpi resolution, and 179 the images were then analysed using the software Gimp 2.8 to determine the leaf area. 180 The SLA was calculated by dividing the leaf area by the oven-dry mass of the leaf. Stem 181 diameter, stem specific density and stem dry matter content were measured on three stems 182 per quadrat. Stem diameter $(\mathrm{mm})$ was measured three times along each vertical level of 183 the fresh stem using a calliper. From the measurements of stem diameter, the projected 184 stem area was calculated using the rectangle area formula and represented the contact 185 area of a stem toward the flow direction. The stem specific density $\left(\mathrm{mg}^{\left.-\mathrm{mm}^{-3}\right)}\right.$ was 186 calculated by dividing the oven-dry mass of the first $20 \mathrm{~cm}$ of the stem by the volume of 187 the stem, measured when still fresh. The volume of the stems was calculated using the 188 formula for the volume of a cylinder, except for the sledge species, which have triangular 189 stems, and for which we used the formula for the volume of a triangular prism. The stem 190 specific density of each height level along the stem was estimated using the volume of 191 each level by assuming the density was homogeneous within the stem section. The stem 192 specific density, representing the structural strength of a stem, was used as the estimation 193 of the plant resistance to the water flow (Burylo et al., 2012; Cornelissen et al., 2003; 194 Pérez-Harguindeguy et al., 2013). The stem dry matter content was calculated from the 195 ratio of the oven dry-mass of the first $20 \mathrm{~cm}$ of the stem and the fresh mass of the stem.

196 The mean values of the measured traits are listed in Appendices A1, A2 and A3. 
197 To characterise the effect of the herbaceous hedge on hydraulic roughness, the density-

198 weighted mean of the trait values was calculated for each trait as the mean value of the

199 trait multiplied by the proportion of the trait, here by the stem density for stem traits and

200 by leaf density for leaf traits. This method does not include plant cover, given that all

201 monospecific vegetation plot presented $100 \%$ cover and more precisely characterise the

202 abundance of traits from stem and leaf densities. These density-weighted traits were

203 determined for each vertical level along the stem (i.e. $0-5 \mathrm{~cm}, 0-10 \mathrm{~cm}$ and $0-20 \mathrm{~cm}$ ).

\subsection{Hydraulic measurements}

We used the same runoff simulator as Richet et al. (2017) to quantify the effect of plant morphological traits on hydraulic roughness (Fig. 1). The simulator allowed the recreation of a flow at chosen discharges and the measurement of hydrological parameters resulting from the presence of plants. The upper and lower parts of the simulator are equipped with flowmeters made of Venturi channels with a flow range of $0.06 \mathrm{~L} . \mathrm{s}^{-1}$ to 6

L. $\mathrm{s}^{-1}$, comprising ultrasound probes that measure the water level in the channel at \pm 1.26

212 mm. This system was manufactured by ISMA, France (Richet et al., 2017). The water

213 was circulating within the system, with the aid of two pumps and a reservoir, in a closed circuit. The central part of the simulator is a channel setup with two galvanised iron sheets. The channel was $60 \mathrm{~cm}$ wide and $5.40 \mathrm{~m}$ long along a $5 \%$ slope. The entire channel was waterproofed using a plastic tarpaulin to avoid any water loss during the experiments.

217 The tarpaulin was placed in order to obtain a smooth channel bottom and limit bottom 218 roughness as much as possible. The roughness of the tarpaulin was determined by experiment using a control plot without any plants and represented a small percentage of 
221 from the head of the channel, in a $17 \mathrm{~cm}$ deep rectangular hole to level the ground with 222 the flow and the slope. The tarpaulin used in the upper part of the channel was placed 223 continually underneath the plot and through the lower part of the channel to avoid water 224 loss by infiltration. The boundary effects were minimal as the plants were left in the 225 wooden frame where they grew, and a wooden plank was placed along each side the entire 226 channel. The small gap areas along the base of the planks and the bottom of the channel 227 were sealed using clay. Along the channel, 7 spacers were set up to measure the 228 topography of the channel bed and the water heights in the backwater and downstream of 229 the plot. Five were located upstream of the plants and two were located downstream. 230 Approximately $1.46 \mathrm{~m}$ from the channel head, the spacers were spaced at $0.75 \mathrm{~m}$. 


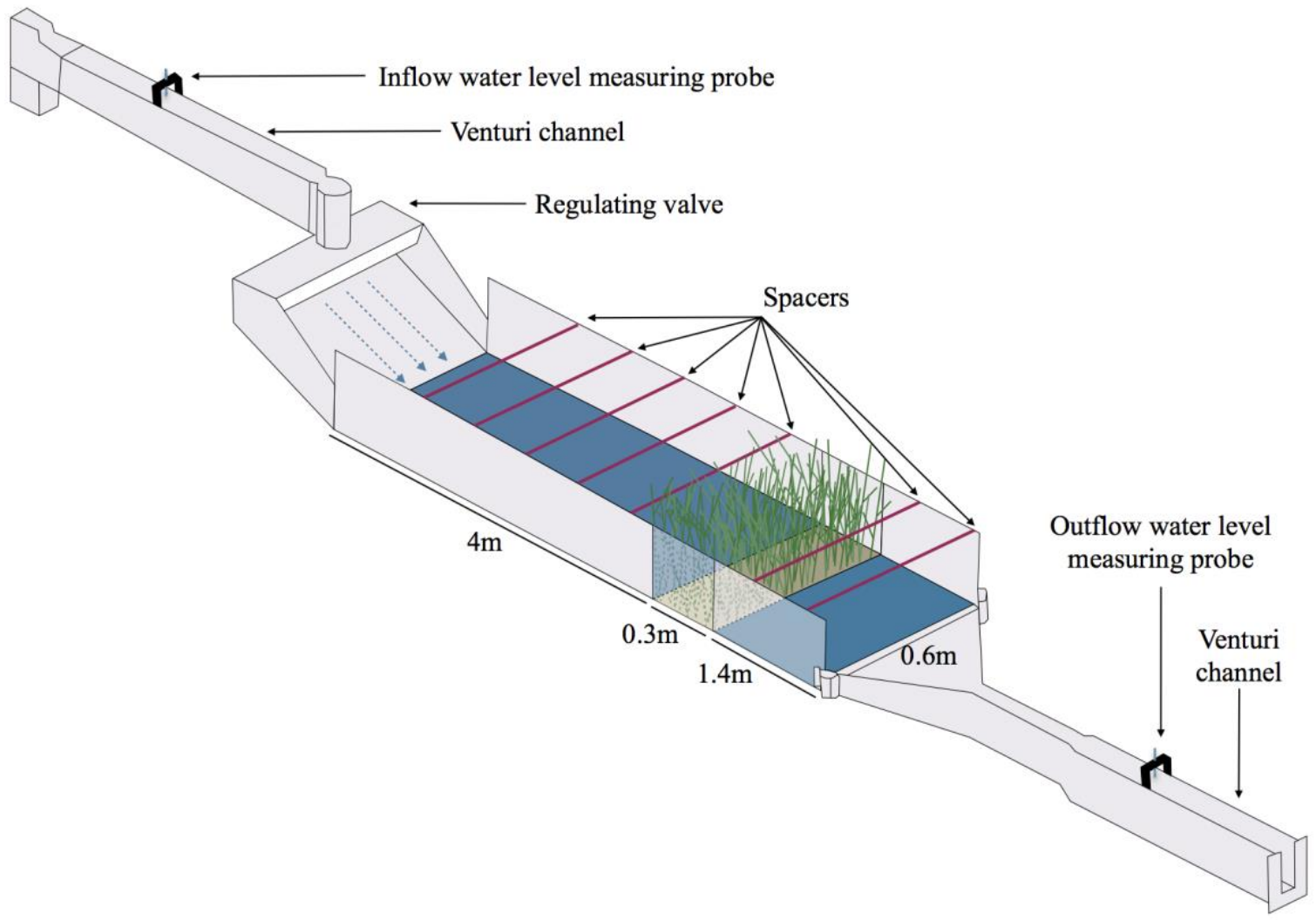

232 Figure 1. Runoff simulator used during the study. 
233 The four discharges used in this study were $2,4,8$ and $11 \mathrm{~L} \cdot \mathrm{s}^{-1} \cdot \mathrm{m}^{-1}$ at $\pm 7 \%$. The tested

234 discharges are observed approximately every $0.5,1,2$ and 5 years, respectively, in 5 ha 235 catchments in the European loess belt with a $5 \mathrm{~m}$-wide thalweg, as precised by Richet et 236 al. (2017). Both upstream and downstream discharges were continuously monitored. 237 Water level were measured when the upstream and downstream discharges were 238 equivalent. No infiltration occurred as the soil in the plots was saturated in water. The 239 backwater and downstream flow levels were measured using the spacers as elevation240 known baselines. The levels were determined by measuring the distance between the top 241 of the water flow and the spacer every $10 \mathrm{~cm}$ from the edges of the channel, corresponding 242 to seven vertical profiles.

243 To express the hydraulic resistance related to the plant presence, we used the unit stream 244 power (USP), a sediment transport capacity index (Govers, 1992; Yang, 1972). USP is 245 defined as the "energy dissipation per unit of time and per unit of weight of the flow" 246 (Govers, 1992), depending on its velocity and the slope:

$247 \quad U S P=V S \quad(1)$

248 where $U S P$ is expressed in $\mathrm{m} \cdot \mathrm{s}^{-1}, V$ is the mean velocity $\left(\mathrm{m} \cdot \mathrm{s}^{-1}\right)$, and $S$ is the channel slope 249 (m.m $\left.{ }^{-1}\right)($ Cao et al., 2015; Hessel et al., 2016; Morgan et al., 1998). The lower the USP is, 250 the greater the hydraulic roughness will be. The mean velocity was calculated using the 251 water levels measured at the closest spacer upstream of the plot. Govers (1990) 252 determined a USP critical value of $0.004 \mathrm{~m} . \mathrm{s}^{-1}$ that indicates that the threshold from which 253 soil is most likely to erode in the loamy soils found in the European loess belt. Govers 254 (1990) established this critical value for bare loess soils with a $\mathrm{D}_{50}$ from $58 \mu \mathrm{m}$ to 218 $255 \mu \mathrm{m}$, at slopes ranging from $1^{\circ}$ to $8^{\circ}$ and for discharges varying from 0.2 to $10 \mathrm{~L} \cdot \mathrm{s}^{-1} \cdot \mathrm{m}^{-1}$. 256 The USP, Manning coefficients and backwater depths are presented in Appendix B. 


\subsection{Data analysis}

259 Principal component analysis (PCA) was conducted to examine the link between each trait. Data used for the PCA included the measured traits in the two quadrats within the 261 plots. Generalised linear models (GLM) for the inverse-link gamma family were then

262 processed to examine the effect of plant morphological traits on the USP at each 263 discharge.

264 Another analysis using GLMs were then used to analyse the relationship between the USP and the significant traits and density-weighted traits identified in the previous step between 0 and $10 \mathrm{~cm}$. These models were run separately for each discharge to highlight differences of trait effects among the discharge levels. To avoid autocorrelation within the models, traits and density-weighted traits were processed in separate models. Due to the small sample size $n$ and ratio $n / K<40$ (where $K$ the number of parameters used in the models), second order Akaike's Information Criterion (AICc) and $\triangle \mathrm{AICc}$ were used to assess the model performance, as recommended in Burnham and Anderson (2002).

$272 \Delta \mathrm{AICc}$ is the difference between the AICc of a model $i$ and the model with the lowest

273 AICc (also characterised as the best model fit). Burnham and Anderson (2002) recognise the models with a $\triangle \mathrm{AICc}<2$ as models with substantial support, which are identified as the best model fits in this study. Models with $\triangle \mathrm{AICc}$ varying between 2 and 7, indicating

276 less support, were also analysed as recommended by Burnham et al. (2011). Akaike 277 weights (wAICc) were used in this study to assess the relative likelihood of the models, 278 as this indicates the probability of a model $i$ being the best among the set of tested models 279 (Brown et al., 2011; Burnham and Anderson, 2002).

280 All the data in this study were analysed using the statistical software R (version 3.3.2). 


\section{Results}

\subsection{Variations of plant morphological traits}

284 Covariation among the seven traits of the 14 species studied were analysed using a PCA 285 (Fig. 2), which showed that the first two principal components explained $71.9 \%$ of the 286 variance. The first principal component (PC1) accounted for $47 \%$ of the total variance 287 and was associated with the projected stem area, the stem diameter and the stem density. 288 The variance of PC1 was explained by the leaf area, the stem specific density and the 289 specific leaf area. Two groups of variables were observed along the PC1 axis: the 290 projected stem area and the stem diameter on the positive end and the stem density on the

291 negative end. The second principal component (PC2) accounted for $24.9 \%$ of the total 292 variance and was explained by the stem dry matter content, which was found on the 293 negative end of the axis. The variance of PC2 was explained by the leaf density and the 294 stem height. 


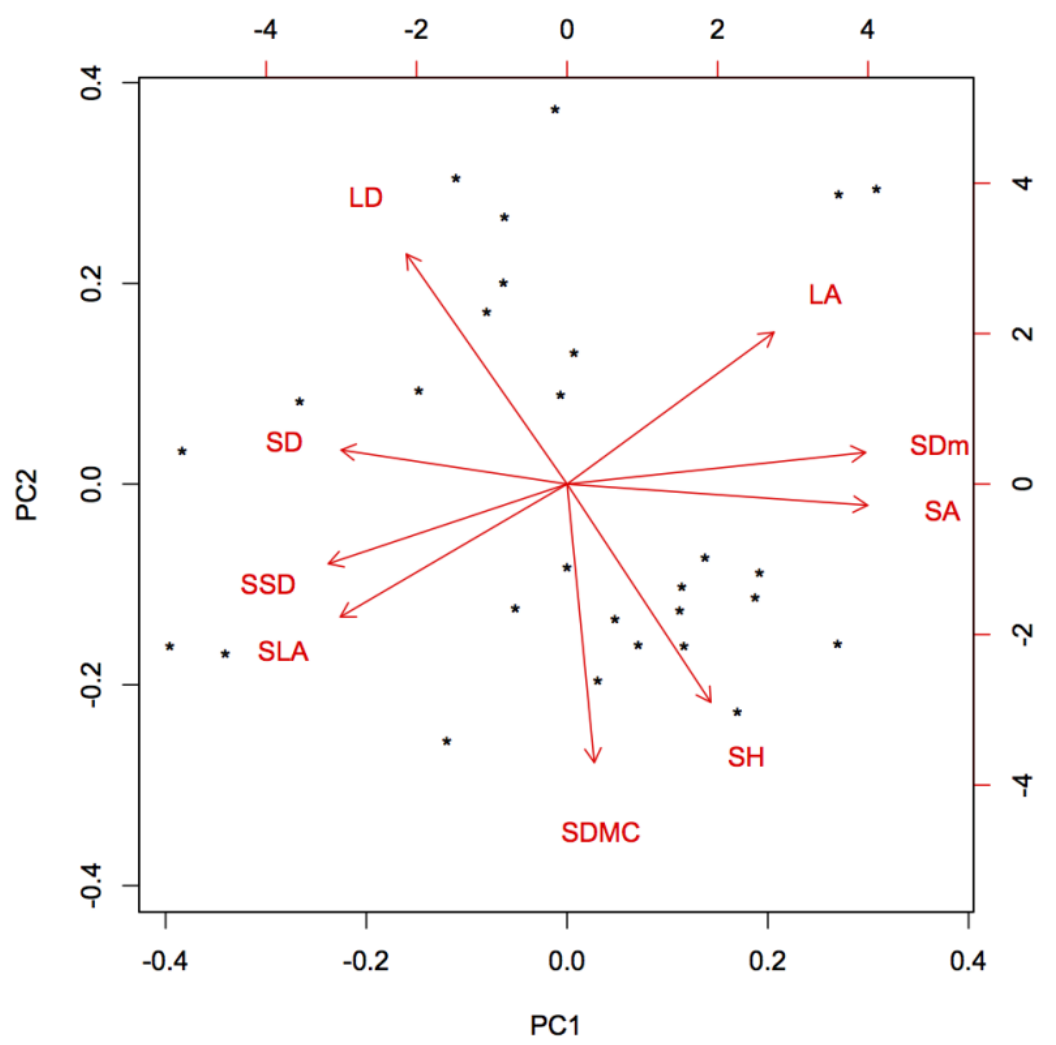

296

297 Figure 2. Principal component analysis of nine morphological traits measured on 14

298 plant species. PC1 explained $47 \%$ of the variance and PC2 explained 24.9\%. LA = leaf

299 area, $\mathrm{LD}=$ leaf density, $\mathrm{SA}=$ projected stem area, $\mathrm{SD}=$ stem density, $\mathrm{SDm}=$ stem

300 diameter, SDMC = stem dry matter content, SLA = specific leaf area, SSD = stem

301 specific density. The vegetative stem height (SH) was added to the other traits for this

302 analysis.

303 
305 The effects of traits on hydraulic roughness were analysed using GLMs to show the traits

306 affecting the USP at each discharge (Table 3$)$. The leaf densities $(0-5 \mathrm{~cm}$ and $0-10 \mathrm{~cm})$

307 were correlated to the USP for the four discharge levels. The leaf area had a significant

308 relationship with the USP at discharges Q1 and Q2, while the leaf density $(0-20 \mathrm{~cm})$ was

309 significant with the USP at discharges Q3 and Q4. The weighted leaf area $(0-5 \mathrm{~cm}, 0-10$

$310 \mathrm{~cm}$ and $0-20 \mathrm{~cm})$, the weighted projected stem area $(0-5 \mathrm{~cm}, 0-10 \mathrm{~cm}$ and $0-20 \mathrm{~cm})$, the

311 weighted stem diameter $(0-5 \mathrm{~cm}, 0-10 \mathrm{~cm}$ and 0-20 cm) and the weighted SLA $(0-5 \mathrm{~cm})$

312 were correlated to the USP at discharges Q1, Q2, Q3 and Q4. The weighted SLA (0-10

$313 \mathrm{~cm}$ ) influenced the USP at discharges Q2, Q3 and Q4. 
315 Table 3. Morphological trait effects on USP for each discharge used. Generalised

316 linear models (GLM) of each trait and density-weighted trait at each stem level in relation

317 to the USP for each discharge. $\mathrm{LA}=$ leaf area, $\mathrm{LD}=$ leaf density, $\mathrm{SA}=$ projected stem

318 area, $\mathrm{SD}=$ stem density, $\mathrm{SDm}=$ stem diameter, $\mathrm{SDMC}=$ stem dry matter content,

319 SLA = specific leaf area, SSD = stem specific density. The density-weighted traits were

320 named by adding "W" at the beginning of their existing abbreviations.

321 


\begin{tabular}{|c|c|c|c|c|c|c|c|c|c|}
\hline \multirow{2}{*}{322} & \multirow{2}{*}{$\begin{array}{c}\text { Level } \\
\text { along the } \\
\text { stem }\end{array}$} & \multicolumn{2}{|c|}{$\mathrm{Q} 1=2 \mathrm{~L} \cdot \mathrm{s}^{-1} \cdot \mathrm{m}^{-1}$} & \multicolumn{2}{|c|}{$\mathrm{Q} 2=4 \mathrm{~L} \cdot \mathrm{s}^{-1} \cdot \mathrm{m}^{-1}$} & \multicolumn{2}{|c|}{$\mathrm{Q} 3=8 \mathrm{~L} \cdot \mathrm{s}^{-1} \cdot \mathrm{m}^{-1}$} & \multicolumn{2}{|c|}{$\mathrm{Q} 4=11 \mathrm{~L} \cdot \mathrm{s}^{-1} \cdot \mathrm{m}^{-1}$} \\
\hline & & AIC & $B$ & AIC & B & AIC & $B$ & AIC & B \\
\hline LA & & -158.15 & $0.04 *$ & -147.27 & $0.03 *$ & -131.38 & $0.02 \mathrm{~ns}$ & -125.83 & $0.02 \mathrm{~ns}$ \\
\hline \multirow[t]{3}{*}{$\mathrm{LD}$} & $0-5 \mathrm{~cm}$ & -159.11 & $1.33 *$ & -150.06 & $1.07 * *$ & -135.45 & $0.78 * *$ & -131.14 & $0.76 * *$ \\
\hline & $0-10 \mathrm{~cm}$ & -157.68 & $0.81 *$ & -148.34 & $0.65 *$ & -134.21 & $0.49 *$ & -129.23 & $0.46 * *$ \\
\hline & $0-20 \mathrm{~cm}$ & -154.49 & $0.44 \mathrm{~ns}$ & -145.21 & $0.37 \mathrm{~ns}$ & -131.54 & $0.29 *$ & -126.12 & $0.27 *$ \\
\hline \multirow[t]{3}{*}{$\mathrm{SA}$} & $0-5 \mathrm{~cm}$ & -152.71 & $0.46 \mathrm{~ns}$ & -141.33 & $0.22 \mathrm{~ns}$ & -126.83 & $0.11 \mathrm{~ns}$ & -120.93 & $0.1 \mathrm{~ns}$ \\
\hline & $0-10 \mathrm{~cm}$ & -152.55 & $0.22 \mathrm{~ns}$ & -141.25 & $0.11 \mathrm{~ns}$ & -126.78 & $0.05 \mathrm{~ns}$ & -120.87 & $0.05 \mathrm{~ns}$ \\
\hline & $0-20 \mathrm{~cm}$ & -151.70 & $0.08 \mathrm{~ns}$ & -140.75 & $0.02 \mathrm{~ns}$ & -126.51 & $0.0048 \mathrm{~ns}$ & -120.58 & $0.0037 \mathrm{~ns}$ \\
\hline $\mathrm{SD}$ & & -151.71 & $0.73 \mathrm{~ns}$ & -142.22 & $0.84 \mathrm{~ns}$ & -128.89 & $0.77 \mathrm{~ns}$ & -122.19 & $0.57 \mathrm{~ns}$ \\
\hline SDMC & & -153.37 & $-707.3 \mathrm{~ns}$ & -143.40 & $-571.4 \mathrm{~ns}$ & -130.15 & $-475.66 \mathrm{~ns}$ & -124.26 & $-429.54 \mathrm{~ns}$ \\
\hline \multirow[t]{3}{*}{$\mathrm{SDm}$} & $0-5 \mathrm{~cm}$ & -152.70 & $22.9 \mathrm{~ns}$ & -141.33 & $11.02 \mathrm{~ns}$ & -126.83 & $5.54 \mathrm{~ns}$ & -120.93 & $5.18 \mathrm{~ns}$ \\
\hline & $0-10 \mathrm{~cm}$ & -152.58 & $22.47 \mathrm{~ns}$ & -141.27 & $10.76 \mathrm{~ns}$ & -126.79 & $5.32 \mathrm{~ns}$ & -120.89 & $4.96 \mathrm{~ns}$ \\
\hline & $0-20 \mathrm{~cm}$ & -152.41 & $21.78 \mathrm{~ns}$ & -141.15 & $9.93 \mathrm{~ns}$ & -126.72 & $4.72 \mathrm{~ns}$ & -120.80 & $4.33 \mathrm{~ns}$ \\
\hline SLA & & -154.96 & $-7.87 \mathrm{~ns}$ & -142.59 & $-4.47 \mathrm{~ns}$ & -127.46 & $-2.39 \mathrm{~ns}$ & -121.92 & $-2.46 \mathrm{~ns}$ \\
\hline \multirow[t]{3}{*}{ SSD } & $0-5 \mathrm{~cm}$ & -153.46 & $-128.71 \mathrm{~ns}$ & -142.06 & $-75.4 \mathrm{~ns}$ & -127.63 & $-49.26 \mathrm{~ns}$ & -121.86 & $-46.93 \mathrm{~ns}$ \\
\hline & $0-10 \mathrm{~cm}$ & -153.64 & $-277 \mathrm{~ns}$ & -141.95 & $-151.2 \mathrm{~ns}$ & -127.38 & $-91.26 \mathrm{~ns}$ & -121.75 & $-93.63 \mathrm{~ns}$ \\
\hline & $0-20 \mathrm{~cm}$ & -153.33 & $-569.8 \mathrm{~ns}$ & -141.35 & $-251.1 \mathrm{~ns}$ & -126.88 & $-134.38 \mathrm{~ns}$ & -121.05 & $-134.77 \mathrm{~ns}$ \\
\hline \multirow[t]{3}{*}{ WLA } & $0-5 \mathrm{~cm}$ & -163.29 & $0.0004 * *$ & -154.63 & $0.0003 * *$ & -138.44 & $0.0002 * *$ & -136.08 & $0.0002 * *$ \\
\hline & $0-10 \mathrm{~cm}$ & -163.26 & $0.0003 * *$ & -153.79 & $0.0002 * *$ & -137.69 & $\mathbf{0 . 0 0 0 1} * *$ & -135.63 & $0.0001 * *$ \\
\hline & $0-20 \mathrm{~cm}$ & -163.44 & $0.0002 * *$ & -153.65 & $0.0001 * *$ & -137.78 & $0.0001 * *$ & -136.37 & $0.0001 * *$ \\
\hline \multirow[t]{3}{*}{ WSA } & $0-5 \mathrm{~cm}$ & -161.43 & $0.02 * *$ & -154.14 & $0.02 * *$ & -141.02 & $0.02 * *$ & -133.45 & $0.01 * *$ \\
\hline & $0-10 \mathrm{~cm}$ & -160.97 & $0.01 * *$ & -153.49 & $0.01 * *$ & -140.30 & $0.0081 * *$ & -132.81 & $0.0071 * *$ \\
\hline & $0-20 \mathrm{~cm}$ & -158.44 & $0.0055 *$ & -149.75 & $0.0046 *$ & -136.37 & $0.0036 * *$ & -129.07 & $0.0031 *$ \\
\hline WSDMC & & -151.38 & $1.72 \mathrm{~ns}$ & -141.76 & $2.31 \mathrm{~ns}$ & -128.25 & $2.14 \mathrm{~ns}$ & -121.66 & $1.51 \mathrm{~ns}$ \\
\hline \multirow[t]{3}{*}{ WSDm } & $0-5 \mathrm{~cm}$ & -161.43 & $1.25 * *$ & -154.14 & $1.05 * *$ & -141.02 & $0.82 * *$ & -133.45 & $0.71 * *$ \\
\hline & $0-10 \mathrm{~cm}$ & -161.06 & $1.24 * *$ & -153.64 & $1.05 * *$ & -140.46 & $\mathbf{0 . 8 2} * *$ & -132.96 & $0.71 * *$ \\
\hline & $0-20 \mathrm{~cm}$ & -160.46 & $1.21 *$ & -152.56 & $1.01 * *$ & -139.27 & $0.79 * *$ & -131.86 & $0.68 * *$ \\
\hline \multirow[t]{3}{*}{ WSLA } & $0-5 \mathrm{~cm}$ & -157.33 & $0.06 *$ & -148.47 & $0.05 *$ & -134.37 & $0.04 *$ & -129.65 & $0.04 * *$ \\
\hline & $0-10 \mathrm{~cm}$ & -154.34 & $0.03 \mathrm{~ns}$ & -145.19 & $0.03 *$ & -131.64 & $0.02 *$ & -125.92 & $0.02 *$ \\
\hline & $0-20 \mathrm{~cm}$ & -151.38 & $0.0058 \mathrm{~ns}$ & -141.71 & $0.0076 \mathrm{~ns}$ & -128.17 & $0.007 \mathrm{~ns}$ & -122.10 & $0.0061 \mathrm{~ns}$ \\
\hline \multirow[t]{3}{*}{ WSSD } & $0-5 \mathrm{~cm}$ & -151.10 & $0.12 \mathrm{~ns}$ & -141.05 & $0.22 \mathrm{~ns}$ & -127.32 & $0.23 \mathrm{~ns}$ & -121.02 & $0.15 \mathrm{~ns}$ \\
\hline & $0-10 \mathrm{~cm}$ & -151.07 & $0.19 \mathrm{~ns}$ & -141.03 & $0.41 \mathrm{~ns}$ & -127.32 & $0.45 \mathrm{~ns}$ & -120.99 & $0.28 \mathrm{~ns}$ \\
\hline & $0-20 \mathrm{~cm}$ & -151.04 & $0.23 \mathrm{~ns}$ & -141.00 & $0.8 \mathrm{~ns}$ & -127.33 & $0.91 \mathrm{~ns}$ & -121.00 & $0.58 \mathrm{~ns}$ \\
\hline
\end{tabular}


323 From the results in Table 3, GLMs were used to highlight traits and density-weighted

324 traits $(0-10 \mathrm{~cm})$ that have a greater impact on the USP within the traits previously

325 identified as significantly impacting the USP (Fig 3, Table 4, Table 5). The GLMs for

326 single traits (Table 4) highlighted that the combination of leaf area and leaf density was

327 the best model fit for all discharges (wAICc > 0.50), although the leaf density was also a

328 good fit for the data at discharges Q3 and Q4 (wAICc $=0.39$ and wAICc $=0.34$,

329 respectively). The results of the density-weighted trait GLMs (Table 5) showed that

330 models USP WLA + WSA and USP WLA + WSDm were the best fit for all

331 discharges, with cumulative wAICc ranging from 0.75 at discharge Q1 to 0.84 at Q4,

332 showing a growing significance along with the discharge gradient. However, the ranking

333 of importance changed with the discharges, as USP WLA + WSA was greater for

334 discharges Q1 and Q4, USP WLA + WSDm was greater for Q3 and both combinations

335 were equivalent for Q2.

336 

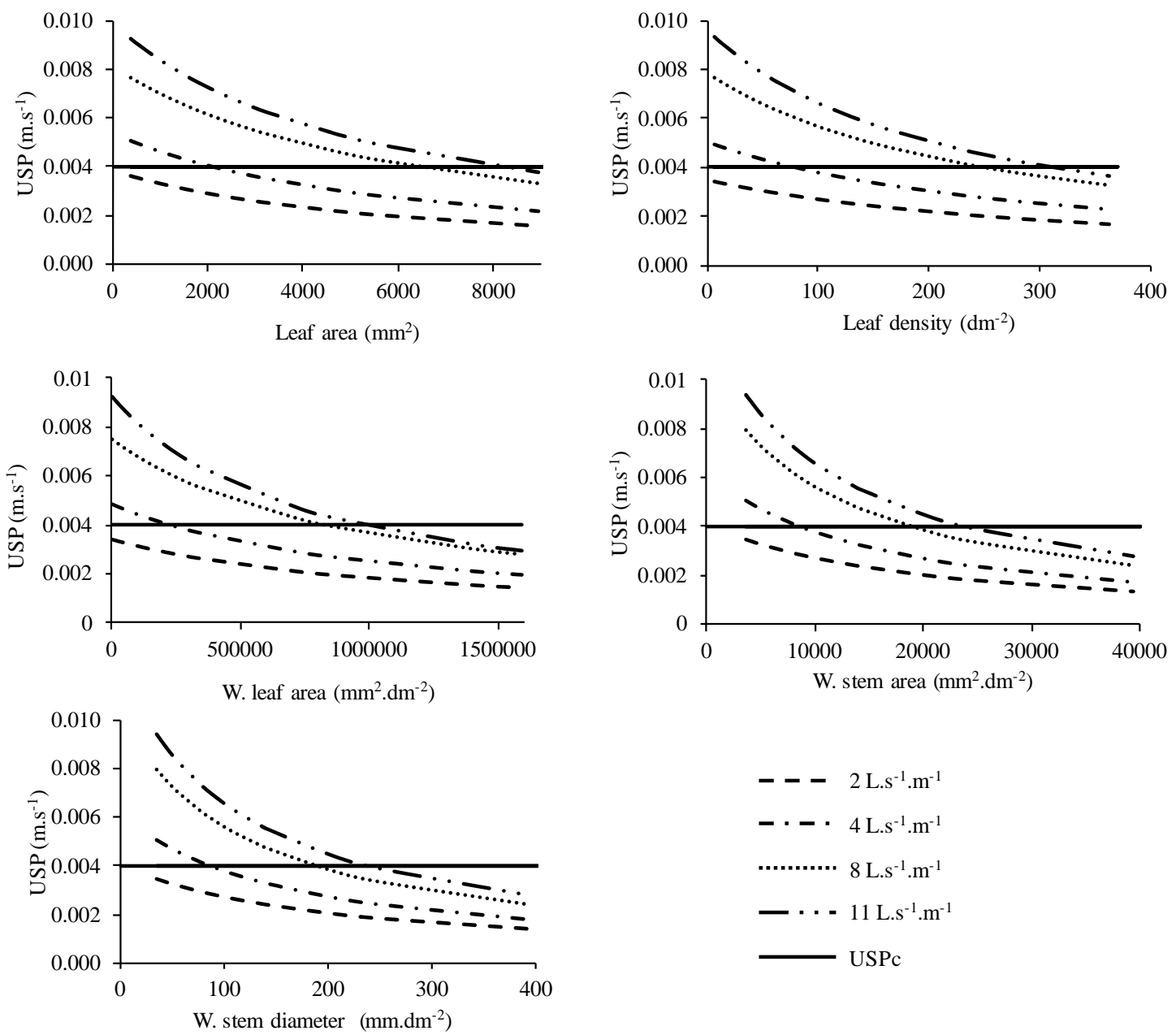

338 Figure 3. Relationship between $U S P$ and traits and density-weighted traits identified

339 as the best fit to hydraulic roughness at $\mathbf{0}-\mathbf{1 0} \mathbf{~ c m}$. USPc represents the threshold of

$340 \quad 0.004 \mathrm{~m} . \mathrm{s}^{-1}$ from which soil is likely to erode in loamy soils found in the European loess

341 belt (Govers, 1990). 
343 discharge used. The models are sorted from the smallest $\triangle \mathrm{AICc}$ to the highest $\triangle \mathrm{AICc}$ at

344 each discharge used.

345

\begin{tabular}{|c|c|c|c|c|}
\hline Discharge & Models & $\mathrm{AICc}$ & $\triangle \mathrm{AICc}$ & wAICc \\
\hline \multirow{3}{*}{$\mathrm{Q} 1=2 \mathrm{~L} \cdot \mathrm{s}^{-1} \cdot \mathrm{m}^{-1}$} & $\mathrm{USP} \sim \mathrm{LA}+\mathrm{LD}$ & -158.68 & 0.0 & 0.707 \\
\hline & $\mathrm{USP} \sim \mathrm{LA}$ & -155.75 & 2.9 & 0.164 \\
\hline & $\mathrm{USP} \sim \mathrm{LD}$ & -155.28 & 3.4 & 0.129 \\
\hline \multirow{3}{*}{$\mathrm{Q} 2=4 \mathrm{~L} \cdot \mathrm{s}^{-1} \cdot \mathrm{m}^{-1}$} & $\mathrm{USP} \sim \mathrm{LA}+\mathrm{LD}$ & -148.93 & 0.0 & 0.737 \\
\hline & $\mathrm{USP} \sim \mathrm{LD}$ & -145.94 & 3.0 & 0.166 \\
\hline & $\mathrm{USP} \sim \mathrm{LA}$ & -144.87 & 4.1 & 0.097 \\
\hline \multirow{3}{*}{$\mathrm{Q} 3=8 \mathrm{~L} \cdot \mathrm{s}^{-1} \cdot \mathrm{m}^{-1}$} & $\mathrm{USP} \sim \mathrm{LA}+\mathrm{LD}$ & -132.34 & 0.0 & 0.512 \\
\hline & $\mathrm{USP} \sim \mathrm{LD}$ & -131.81 & 0.5 & 0.393 \\
\hline & $\mathrm{USP} \sim \mathrm{LA}$ & -128.98 & 3.4 & 0.096 \\
\hline \multirow{3}{*}{$\mathrm{Q} 4=11 \mathrm{~L} \cdot \mathrm{s}^{-1} \cdot \mathrm{m}^{-1}$} & $\mathrm{USP} \sim \mathrm{LA}+\mathrm{LD}$ & -127.94 & 0.0 & 0.595 \\
\hline & $\mathrm{USP} \sim \mathrm{LD}$ & -126.83 & 1.1 & 0.342 \\
\hline & $\mathrm{USP} \sim \mathrm{LA}$ & -123.43 & 4.5 & 0.063 \\
\hline \multicolumn{5}{|c|}{$\begin{array}{l}\text { Full model was: USP } \sim \mathrm{LA}+\mathrm{LD} ; \mathrm{LD} \text { from }(0-10 \mathrm{~cm}) . \text { AICc }=\text { second order } \\
\text { Aikake's Information Criterion; see text for more details on } \triangle \mathrm{AICc} \text { and } \\
\text { wAICc. } \mathrm{LA}=\text { leaf area and } \mathrm{LD}=\text { leaf density }\end{array}$} \\
\hline
\end{tabular}


347 variables for each discharge used. The models are sorted from the smallest $\Delta \mathrm{AICc}$ to

348 the highest $\triangle \mathrm{AICc}$ for each discharge used.

\begin{tabular}{|c|c|c|c|c|}
\hline Discharge & Models & $\mathrm{AICc}$ & $\triangle \mathrm{AICc}$ & wAICc \\
\hline \multirow{8}{*}{$\mathrm{Q} 1=2 \mathrm{~L} \cdot \mathrm{s}^{-1} \cdot \mathrm{m}^{-1}$} & $\mathrm{USP} \sim \mathrm{WLA}+\mathrm{WSA}$ & -165.33 & 0.00 & 0.377 \\
\hline & $\mathrm{USP} \sim \mathrm{WLA}+\mathrm{WSDm}$ & -165.29 & 0.04 & 0.370 \\
\hline & $\mathrm{USP} \sim \mathrm{WLA}+\mathrm{WSLA}+\mathrm{WSDm}$ & -161.93 & 3.40 & 0.069 \\
\hline & $\mathrm{USP} \sim \mathrm{WLA}+\mathrm{WSA}+\mathrm{WSLA}$ & -161.92 & 3.41 & 0.069 \\
\hline & $\mathrm{USP} \sim \mathrm{WLA}$ & -160.86 & 4.47 & 0.040 \\
\hline & $\mathrm{USP} \sim \mathrm{WLA}+\mathrm{WSDm}+\mathrm{WSA}$ & -160.48 & 4.85 & 0.033 \\
\hline & $\mathrm{USP} \sim \mathrm{WSDm}$ & -158.66 & 6.67 & 0.013 \\
\hline & $\mathrm{USP} \sim \mathrm{WSA}$ & -158.57 & 6.76 & 0.013 \\
\hline \multirow{5}{*}{$\mathrm{Q} 2=4 \mathrm{~L} \cdot \mathrm{s}^{-1} \cdot \mathrm{m}^{-1}$} & $\mathrm{USP} \sim \mathrm{WLA}+\mathrm{WSA}$ & -160.22 & 0.00 & 0.412 \\
\hline & $\mathrm{USP} \sim \mathrm{WLA}+\mathrm{WSDm}$ & -160.22 & 0.00 & 0.412 \\
\hline & $\mathrm{USP} \sim \mathrm{WLA}+\mathrm{WSLA}+\mathrm{WSDm}$ & -156.45 & 3.77 & 0.063 \\
\hline & $\mathrm{USP} \sim \mathrm{WLA}+\mathrm{WSA}+\mathrm{WSLA}$ & -156.38 & 3.84 & 0.060 \\
\hline & $\mathrm{USP} \sim \mathrm{WLA}+\mathrm{WSDm}+\mathrm{WSA}$ & -155.16 & 5.05 & 0.033 \\
\hline \multirow{7}{*}{$\mathrm{Q} 3=8 \mathrm{~L} \cdot \mathrm{s}^{-1} \cdot \mathrm{m}^{-1}$} & $\mathrm{USP} \sim \mathrm{WLA}+\mathrm{WSDm}$ & -143.44 & 0.00 & 0.405 \\
\hline & $\mathrm{USP} \sim \mathrm{WLA}+\mathrm{WSA}$ & -143.44 & 0.01 & 0.404 \\
\hline & $\mathrm{USP} \sim \mathrm{WLA}+\mathrm{WSLA}+\mathrm{WSDm}$ & -138.78 & 4.67 & 0.039 \\
\hline & $\mathrm{USP} \sim \mathrm{WLA}+\mathrm{WSA}+\mathrm{WSLA}$ & -138.73 & 4.71 & 0.038 \\
\hline & $\mathrm{USP} \sim \mathrm{WLA}+\mathrm{WSDm}+\mathrm{WSA}$ & -138.39 & 5.06 & 0.032 \\
\hline & $\mathrm{USP} \sim \mathrm{WSDm}$ & -138.06 & 5.39 & 0.027 \\
\hline & $\mathrm{USP} \sim \mathrm{WSA}$ & -137.9 & 5.55 & 0.025 \\
\hline \multirow{5}{*}{$\mathrm{Q} 4=11 \mathrm{~L} \cdot \mathrm{s}^{-1} \cdot \mathrm{m}^{-1}$} & $\mathrm{USP} \sim \mathrm{WLA}+\mathrm{WSA}$ & -140.87 & 0.00 & 0.423 \\
\hline & $\mathrm{USP} \sim \mathrm{WLA}+\mathrm{WSDm}$ & -140.86 & 0.02 & 0.419 \\
\hline & $\mathrm{USP} \sim \mathrm{WLA}+\mathrm{WSLA}+\mathrm{WSDm}$ & -136.7 & 4.17 & 0.053 \\
\hline & $\mathrm{USP} \sim \mathrm{WLA}+\mathrm{WSA}+\mathrm{WSLA}$ & -136.68 & 4.20 & 0.052 \\
\hline & $\mathrm{USP} \sim \mathrm{WLA}+\mathrm{WSDm}+\mathrm{WSA}$ & -135.85 & 5.03 & 0.034 \\
\hline \multicolumn{5}{|c|}{$\begin{array}{l}\text { Full model was: USP } \sim \text { WLA }+ \text { WSA }+ \text { WSLA }+ \text { WSDm. All variables are for traits }(0-10 \\
\mathrm{cm}) . \text { AICc }=\text { second order Aikake's Information Criterion; see text for more details on } \triangle A I C c \\
\text { and wAICc. WLA = weighted leaf area, WSA = weighted projected stem area, } \\
\text { WSDm = weighted stem diameter, WSLA = weighted specific leaf area. }\end{array}$} \\
\hline
\end{tabular}


351 Contrary to processes of soil detachment by water flow (De Baets and Poesen, 2010;

352 Vannoppen et al., 2015) and sediment retention (Burylo et al., 2012), the effect of morphological plant traits on hydraulic roughness corresponds to a lack of research to understand the role of plant and vegetation on soil erosion. This study examined the effects of plant morphological traits on hydraulic roughness for four discharges.

\subsection{Effect of morphological traits and density-weighted traits on hydraulic} roughness

Stem and leaf traits influenced hydraulic roughness, given that they constitute a hydraulic brake on water flows. However, some stem and leaf traits may have a greater effect on hydraulic roughness. This study has highlighted that, among the considered aboveground traits involved in soil erosion (i.e., leaf area, SLA, leaf density, stem density, stem diameter, stem specific density, projected stem area and stem dry matter content), only the leaf area and the leaf density presented a significant effect on hydraulic roughness. The leaf traits have a better impact on hydraulic roughness than stem traits, regarding non-weighted traits. The GLMs showed that the combination of leaf density and leaf area

367 better explained the effect on hydraulic roughness than these traits alone for any discharge used. Plant individuals with better trade-off between leaf density and leaf area, meaning high leaf density and long leaves, such as some graminoid species, would have a great impact on mitigating the unit stream power and thus increase hydraulic roughness. These results are in agreement with other studies highlighting the efficiency of several

372 graminoid species in soil erosion mitigation (Isselin-Nondedeu and Bédécarrats, 2007;

373 Morgan, 2004). The absence of the stem density effect on hydraulic roughness is not in 
agreement with the literature where the stem density is considered a main trait impacting

375 flow velocity and soil erosion (Isselin-Nondedeu and Bédécarrats, 2007; Mekonnen et al., 376 2016; Meyer et al., 1995; Morgan and Duzant, 2008; Temple et al., 1987). This

377 contradiction could be explained by the lack of a standard characterisation of all stem and 378 leaf traits involved in hydraulic roughness and soil erosion (e.g. defining the tillers and 379 pseudoculms as stems when characterising the stem density). The stem density is one of 380 the main traits included in hydraulic and soil erosion models such as VFSMOD (Muñoz 381 Carpena and Parsons, 2014) and in studies focusing on the relationship between 382 vegetation and hydraulic roughness or sediment retention (Morgan, 2004; Temple, 1982; Van Dijk et al., 1996; Xiao et al., 2011), which could be improved by considering the

384 effect of other stem traits (e.g., stem diameter). In the trait-based approach, the importance 385 of stem density in the plant-hydraulic roughness relationship lays in its use in the calculation of weighted stem trait values in the vegetation. Indeed, this approach highlighted that mainly density-weighted traits influenced hydraulic roughness. Specifically, all the GLMs included weighted leaf area, indicating its great importance in the increase of hydraulic roughness. Projected stem area or stem diameter showed no

390 significance on the hydraulic roughness at the trait level but, by considering weighted stem traits, weighted projected stem area and weighted stem diameter showed highly significant effects on the unit stream power. The GLMs showed that the best fit model was WSA + WLA (weighted projected stem area + weighted leaf area) as these traits

394 represent the interception area of the leaves and stems with the water flow in the 395 vegetation, i.e., a hydraulic brake. As the stem diameter, projected stem area and leaf area were negatively associated with the stem density, trade-offs among these stem and leaf traits can be considered to improve herbaceous hedge effects on hydraulic roughness. The 
398 effect of weighted SLA, when associated with weighted leaf area and weighted stem

399 diameter or weighted leaf area and weighted projected stem area, was also observed ( 3 <

$400 \Delta \mathrm{AICc}<5)$. Overall, vegetation presenting the best trade-off between stem density and

401 weighted stem diameter, as well as between leaf density and leaf area, will have a greater

402 efficiency to increase hydraulic roughness. Herbaceous hedges that present these

403 weighted leaf and stem traits would be partly composed of graminoid species, given that

404 these present large leaf density, leaf area, stem diameter and a greater hydraulic roughness

405 than non-graminoid species (Isselin-Nondedeu and Bédécarrats, 2007). Stem and leaf

406 densities should be considered to calculate weighted-traits in herbaceous hedges and

407 quantify the effect on soil erosion. Characterisation of trait weights in herbaceous hedges

408 vegetation allowed to highlight the main morphological aboveground traits and their

409 combinations involved in hydraulic roughness, as well as the importance of stem density

410 as a plant marker to examine the effect of vegetation on runoff. As a result, this trait-

411 based approach can be effectively applied at the vegetation level to understand and model

412 runoff and soil erosion.

413

414

4.2. Effects of morphological traits on hydraulic roughness depending on runoff processes

416 Flow rate variations can trigger different soil-plant-water processes (Dabney et al., 2004;

417 Temple et al., 1987; Vieira and Dabney, 2012). The results here are consistent with the 418 hypothesis that the influence of aboveground traits on hydraulic roughness can change 419 with the discharge. The effect of leaf density $(0-20 \mathrm{~cm})$ and leaf area on hydraulic 420 roughness varied with the discharge. The results showed the importance of leaf density 421 in increasing hydraulic roughness at higher discharges $(\triangle \mathrm{AIC}<2)$. However, for lower 
discharges, a combination of leaf area and leaf density should be considered rather than

423 the traits alone. The results for the leaf area are in accordance with the one found by

424 Temple et al. (1987) showing a decreasing impact of the leaf structure with an increasing discharge. At a small discharge $\left(2 \mathrm{~L} \cdot \mathrm{s}^{-1} \cdot \mathrm{m}^{-1}\right)$, weighted SLA $(0-10 \mathrm{~cm})$ did not present an effect on the hydraulic roughness, but a positive influence was observed at $4 \mathrm{~L} \cdot \mathrm{s}^{-1} \cdot \mathrm{m}^{-1}$. Differences in the influence of leaf density and weighted SLA among the discharges may be interpreted as the water depth being too low to enter into contact with all the leaves between 0 and $20 \mathrm{~cm}$ of each individual and with large SLA until $5 \mathrm{~cm}$ of the vegetation at small discharges. Herbaceous hedges, playing a key role in hydraulic roughness, presents the best trade-off between stem density and diameter, as well as leaf density and area at low discharges, and with increasing water discharge, larger basal leaf density and basal SLA. This study indicates that some trait and density-weighted trait effects on hydraulic roughness are linked to the flow water level. The characterisation of these effects according to flow depth constitutes an advance to model water flows and soil erosion in ecosystems and landscapes.

\subsection{Consequences on sediment retention}

439 As hydraulic roughness is linked to sediment retention and transport capacities (Dabney 440 et al., 2009; Isselin-Nondedeu and Bédécarrats, 2007; Lambrechts et al., 2014; Munoz441 Carpena et al., 1999), plant morphological traits, which have positive effects on hydraulic 442 roughness, can be discussed with studies highlighting plant trait effects on sediment 443 retention. Indeed, results showed the positive effect of the leaf area on hydraulic 444 roughness, whereas there was no effect of stem specific density at small discharges, such as $2 \mathrm{~L} . \mathrm{s}^{-1} \cdot \mathrm{m}^{-1}$, which is consistent with Burylo et al. (2012) on the sediment retention 
capacity for more intense erosion processes. Results display the greater impact of density-

447 weighted traits, which were previously not considered in studies on plant trait effects on 448 sediment retention. The density-weighted trait approach is therefore important in understanding the plant-soil interaction involved in soil erosion. Application of this trait-based approach in ecohydrology involves using the results to manage the reduction of soil erosion. Use of the unit stream power allows to characterise the plant efficiency with regard to sediment retention, with a critical USP (USPc) value of $0.004 \mathrm{~m} . \mathrm{s}^{-1}$ determined by (Govers, 1990), which indicates the threshold from which soil is most likely to erode in loamy soils found in the European loess belt. From identified traits and density-weighted traits presenting an effect on hydraulic roughness and their values $\left(U S P<0.004 \mathrm{~m} . \mathrm{s}^{-1}\right)$ plant species selection could be performed to create new herbaceous ecosystems that will be efficient to reduce runoff and further sediment retention on degraded areas (e.g., bare soils in degraded agroecosystems, urban and mining habitats) (Fig. 3).

\section{Conclusions}

462 This trait-based ecohydrology study allows the identification of important plant traits that

463 influence the hydraulic roughness. The results indicate the stronger effect of density464 weighted traits, showing that communities with the best trade-offs between stem density, 465 diameter and leaf area are the key to mitigate soil erosion. This new knowledge in the 466 relationship between plant functional traits with hydraulic roughness and soil erosion 467 constitutes a new advancement for modelling vegetation effects on soil erosion and 468 creating new herbaceous ecosystems in degraded areas (e.g. bare soils of agroecosystems, 469 mining and urban habitats). These newly reconstructed herbaceous ecosystems will play 

an important role in soil erosion mitigation. Future work should (1) include these

471 relationships between aboveground traits and hydraulic roughness in existing models to estimate the transport and sediment retention capacities of flows and design herbaceous hedges to mitigate soil erosion and (2) examine the effect of functional diversity on runoff and soil erosion, as it could influence hydraulic roughness by ecologically complementing aboveground biomass and, more precisely, by limiting vegetation lodging.

\section{Acknowledgements}

The authors thank the funders of this study: Agence de l'Eau Seine-Normandie (Seine-

to Dr. Yves le Bissonnais and Dr. Freddy Rey for their scientific comments on the methods of our study and M. Jean-Baptiste Richet for his insightful comments and technical advice.

\section{References}

486

487

488

489

490

491

492

493

494

495

496

497

498

499

500

Akram, S., Yu, B., Ghadiri, H., Rose, C., Hussein, J., 2014. The links between water profile, net deposition and erosion in the design and performance of stiff grass hedges. J. Hydrol. 510, 472-479. https://doi.org/10.1016/j.jhydrol.2014.01.001

Berendse, F., van Ruijven, J., Jongejans, E., Keesstra, S., 2015. Loss of plant species diversity reduces soil erosion resistance. Ecosystems. 18, 881-888. https://doi.org/10.1007/s10021-015-9869-6

Blanco-Canqui, H., Gantzer, C.J., Anderson, S.H., 2006. Performance of grass barriers and filter strips under interrill and concentrated flow. J. Environ. Qual. 35, 1969. https://doi.org/10.2134/jeq2006.0073

Boardman, J., Poesen, J. (Eds.), 2006. Soil Erosion in Europe. John Wiley \& Sons, Ltd.

Bochet, E., Poesen, J., Rubio, J.L., 2000. Mound development as an interaction of individual plants with soil, water erosion and sedimentation processes on slopes. Earth Surf. Process. Landf. 25, 847-867.

Brown, K.A., Flynn, D.F.B., Abram, N.K., Ingram, J.C., Johnson, S.E., Wright, P., 2011. Assessing natural resource use by forest-reliant communities in Madagascar using 
functional diversity and functional redundancy metrics. PLoS ONE 6, e24107. https://doi.org/10.1371/journal.pone.0024107

Burnham, K.P., Anderson, D.R., 2002. Model Selection and Multimodel Inference: A Practical Information-Theoretic Approach, 2nd ed. Springer, New York.

Burnham, K.P., Anderson, D.R., Huyvaert, K.P., 2011. AIC model selection and multimodel inference in behavioral ecology: Some background, observations, and comparisons. Behav. Ecol. Sociobiol. 65, 23-35. https://doi.org/10.1007/s00265010-1029-6

Burylo, M., Rey, F., Bochet, E., Dutoit, T., 2012. Plant functional traits and species ability for sediment retention during concentrated flow erosion. Plant Soil 353, 135-144. https://doi.org/10.1007/s11104-011-1017-2

Cantalice, J.R.B., Melo, R.O., Silva, Y.J.A.B., Cunha Filho, M., Araújo, A.M., Vieira, L.P., Bezerra, S.A., Barros, G., Singh, V.P., 2015. Hydraulic roughness due to submerged, emergent and flexible natural vegetation in a semiarid alluvial channel. J. Arid Environ. 114, 1-7. https://doi.org/10.1016/j.jaridenv.2014.10.012

Cao, L., Zhang, Y., Lu, H., Yuan, J., Zhu, Y., Liang, Y., 2015. Grass hedge effects on controlling soil loss from concentrated flow: A case study in the red soil region of China. Soil Tillage Res. 148, 97-105. https://doi.org/10.1016/j.still.2014.12.009

Cornelissen, J.H.C., Lavorel, S., Garnier, E., Diaz, S., Buchmann, N., Gurvich, D.E., Reich, P.B., ter Steege, H., Morgan, H.D., van der Heijden, M.G.A., Pausas, J.G., Poorter, H., 2003. A handbook of protocols for standardised and easy measurement of plant functional traits worldwide. Aust. J. Bot. 51, 335-380.

Dabney, S.M., McGregor, K.C., Wilson, G.V., Cullum, R.F., 2009. How management of grass hedges affects their erosion reduction potential. Soil Sci. Soc. Am. J. 73, 241. https://doi.org/10.2136/sssaj2007.0434

Dabney, S.M., Meyer, L.D., Harmon, W.C., Alonso, C.V., Foster, G.R., 1995. Depositional patterns of sediment trapped by grass hedges. Trans. ASAE 38, 1719-1729.

Dabney, S.M., Shields Jr, F.D., Temple, D.M., Langendoen, E.J., 2004. Erosion processes in gullies modified by establishing grass hedges. Trans. ASAE 47, 1561.

De Baets, S., Poesen, J., 2010. Empirical models for predicting the erosion-reducing effects of plant roots during concentrated flow erosion. Geomorphology. 118, 425-432. https://doi.org/10.1016/j.geomorph.2010.02.011

De Baets, S., Poesen, J., Gyssels, G., Knapen, A., 2006. Effects of grass roots on the erodibility of topsoils during concentrated flow. Geomorphology. 76, 54-67. https://doi.org/10.1016/j.geomorph.2005.10.002

Dillaha, T.A., Reneau, R.B., Mostaghimi, S., Lee, D., 1989. Vegetative filter strips for agricultural nonpoint source pollution control. Trans. ASAE 32, 513-0519.

Dosskey, M.G., Vidon, P., Gurwick, N.P., Allan, C.J., Duval, T.P., Lowrance, R., 2010. The role of riparian vegetation in protecting and improving chemical water quality in streams. J. Am. Water Resour. Assoc. 1-18. https://doi.org/10.1111/j.17521688.2010.00419.x

Faucon, M.-P., Houben, D., Lambers, H., 2017. Plant functional traits: soil and ecosystem $\begin{array}{llll}\text { services. Trends } & \text { Plant }\end{array}$ https://doi.org/10.1016/j.tplants.2017.01.005 
Garnier, E., Navas, M.-L., 2012. A trait-based approach to comparative functional plant ecology: concepts, methods and applications for agroecology. A review. Agron. Sustain. Dev. 32, 365-399.

Gobin, A., Govers, G., Jones, R., Kirkby, M., Kosmas, C., Gentile, A.R., 2003. Assessment and reporting on soil erosion: background and workshop report. (Technical No. 94). European Environment Agency, Copenhagen.

Govers, G., 1992. Relationship between discharge, velocity and flow area for rills eroding loose, non-layered materials. Earth Surf. Process. Landf. 17, 515-528.

Govers, G., 1990. Empirical relationships for the transport capacity of overland flow. Int. Assoc. Hydrol. Sci. 189, 45-63.

Graff, C.D., Sadeghi, A.M., Lowrance, R.R., Williams, R.G., 2005. Quantifying the sensitivity of the riparian ecosystem management model (REMM) to changes in climate and buffer characteristics common to conservation practices. Trans. ASAE 48, 1377-1387.

Gyssels, G., Poesen, J., Bochet, E., Li, Y., 2005. Impact of plant roots on the resistance of soils to erosion by water: a review. Prog. Phys. Geogr. 29, 189-217. https://doi.org/10.1191/0309133305pp443ra

Haan, C.T., Barfield, B.J., Hayes, J.C., 1994. Design Hydrology and Sedimentology for Small Catchments. Academic Press.

Hayes, J.C., Barfield, B.J., Barnhisel, R.I., 1978. Evaluation of grass characteristics related to sediment filtration. ASAE 78-2513, 21.

Hessel, R., Jetten, V.G., Liu, B., Qiu, Y., 2016. Evaluating effects of soil and water management and land use change on the Loess Plateau of China using LISEM, in: Morgan, R.P.C., Nearing, M. (Eds.), Handbook of Erosion Modelling. John Wiley and Sons, pp. 223-248.

Hussein, J., Yu, B., Ghadiri, H., Rose, C., 2007. Prediction of surface flow hydrology and sediment retention upslope of a vetiver buffer strip. J. Hydrol. 338, 261-272.

Isselin-Nondedeu, F., Bédécarrats, A., 2007. Influence of alpine plants growing on steep slopes on sediment trapping and transport by runoff. Catena. 71, 330-339. https://doi.org/10.1016/j.catena.2007.02.001

Järvelä, J., 2002. Flow resistance of flexible and stiff vegetation: A flume study with natural plants. J. Hydrol. 269, 44-54.

Knapen, A., Poesen, J., Govers, G., Gyssels, G., Nachtergaele, J., 2007. Resistance of soils to concentrated flow erosion: A review. Earth-Sci. Rev. 80, 75-109. https://doi.org/10.1016/j.earscirev.2006.08.001

Lambinon, J., Delvosalle, L., Duvigneaud, J., 2012. Nouvelle flore de la Belgique, du G.D. de Luxembourg, du nord de la France et des régions voisines, 6th ed.

Lambrechts, T., François, S., Lutts, S., Muñoz-Carpena, R., Bielders, C.L., 2014. Impact of plant growth and morphology and of sediment concentration on sediment retention efficiency of vegetative filter strips: Flume experiments and VFSMOD modeling. J. Hydrol. 511, 800-810. https://doi.org/10.1016/j.jhydrol.2014.02.030

Lavorel, S., Garnier, E., 2002. Predicting changes in community composition and ecosystem functioning from plant traits: Revisiting the Holy Grail. Funct. Ecol. $16,545-556$.

Le Bissonnais, Y., Cerdan, O., Lecomte, V., Benkhadra, H., Souchère, V., Martin, P., 2005. Variability of soil surface characteristics influencing runoff and interrill erosion. CATENA 62, 111-124. https://doi.org/10.1016/j.catena.2005.05.001 
603

604

605

606

607

608

609

610

611

612

613

614

615

616

617

618

619

620

621

622

623

624

625

626

627

628

629

630

631

632

633

634

635

636

637

638

639

Lowrance, R.R., Altier, L.S., Newbold, J.D., Schnabel, R.R., Groffman, P.M., Denver, J.M., Correll, D.L., Gilliam, J.W., Robinson, J.L., Brinsfield, R.B., Staver, K.W., Lucas, W., Todd, A.H., 1995. Water quality functions of riparian forest buffer systems in the Chesapeake Bay watershed (Technology transfer report No. EPA 903-R-95-004). U.S. Environmental Protection Agency, Chesapeake Bay Program.

Ludwig, J.A., Wilcox, B.P., Breshears, D.D., Tongway, D.J., Imeson, A.C., 2005. Vegetation patches and runoff-erosion as interacting ecohydrological processes in semiarid landscapes. Ecology. 86, 288-297. https://doi.org/10.1890/03-0569

Mekonnen, M., Keesstra, S.D., Ritsema, C.J., Stroosnijder, L., Baartman, J.E.M., 2016. Sediment trapping with indigenous grass species showing differences in plant traits in northwest Ethiopia. Catena 147, 755-763. https://doi.org/10.1016/j.catena.2016.08.036

Meyer, L.D., Dabney, S.M., Harmon, W.C., 1995. Sediment-trapping effectiveness of stiff-grass hedges. Am. Soc. Agric. Eng. 38, 809-815.

Morgan, R.P.C., 2004. Vegetative-based technologies for erosion control, in: Stokes, A., Spanos, I., Norris, J.E., Cammeraat, E. (Eds.), Eco- and Ground Bio-Engineering: The Use of Vegetation to Improve Slope Stability. Springer, Dordrecht, The Netherlands, pp. 265-272.

Morgan, R.P.C., Duzant, J.H., 2008. Modified MMF (Morgan-Morgan-Finney) model for evaluating effects of crops and vegetation cover on soil erosion. Earth Surf. Process. Landf. 33, 90-106. https://doi.org/10.1002/esp.1530

Morgan, R.P.C., Quinton, J.N., Smith, R.E., Govers, G., Poesen, J.W.A., Chisci, G., Torri, D., 1998. The EUROSEM model, in: Boardman, J., Favis-Mortlock, D. (Eds.), Modelling Soil Erosion by Water. Springer Science and Business Media, pp. $389-398$.

Muñoz Carpena, R., Parsons, J.E., 2014. VFSMOD - Vegetative filter strips modelling system (Model documentation and user's manual No. 6.x). University of Florida.

Munoz-Carpena, R., Parsons, J.E., Gilliam, J.W., 1999. Modeling hydrology and sediment transport in vegetative filter strips. J. Hydrol. 214, 111-129.

Ouin, A., Burel, F., 2002. Influence of herbaceous elements on butterfly diversity in hedgerow agricultural landscapes. Agric. Ecosyst. Environ. 93, 45-53.

Pérez-Harguindeguy, N., Díaz, S., Garnier, E., Lavorel, S., Poorter, H., Jaureguiberry, P., Bret-Harte, M.S., Cornwell, W.K., Craine, J.M., Gurvich, D.E., Urcelay, C., Veneklaas, E.J., Reich, P.B., Poorter, L., Wright, I.J., Ray, P., Enrico, L., Pausas, J.G., de Vos, A.C., Buchmann, N., Funes, G., Quétier, F., Hodgson, J.G., Thompson, K., Morgan, H.D., ter Steege, H., Sack, L., Blonder, B., Poschlod, P., Vaieretti, M.V., Conti, G., Staver, A.C., Aquino, S., Cornelissen, J.H.C., 2013. New handbook for standardised measurement of plant functional traits worldwide. Aust. J. Bot. 61, 167-234. https://doi.org/10.1071/BT12225

Richet, J.-B., Ouvry, J.-F., Saunier, M., 2017. The role of vegetative barriers such as fascines and dense shrub hedges in catchment management to reduce runoff and erosion effects: Experimental evidence of efficiency, and conditions of use. Ecol. Eng. 103, 455-469. https://doi.org/10.1016/j.ecoleng.2016.08.008

Ruiz-Colmenero, M., Bienes, R., Eldridge, D.J., Marques, M.J., 2013. Vegetation cover reduces erosion and enhances soil organic carbon in a vineyard in the central Spain. Catena. 104, 153-160. https://doi.org/10.1016/j.catena.2012.11.007 
Smith, J., Potts, S., Eggleton, P., 2008. The value of sown grass margins for enhancing soil macrofaunal biodiversity in arable systems. Agric. Ecosyst. Environ. 127, 119-125. https://doi.org/10.1016/j.agee.2008.03.008

Stokes, A., Douglas, G.B., Fourcaud, T., Giadrossich, F., Gillies, C., Hubble, T., Kim, J.H., Loades, K.W., Mao, Z., McIvor, I.R., Mickovski, S.B., Mitchell, S., Osman, N., Phillips, C., Poesen, J., Polster, D., Preti, F., Raymond, P., Rey, F., Schwarz, M., Walker, L.R., 2014. Ecological mitigation of hillslope instability: ten key issues facing researchers and practitioners. Plant Soil 377, 1-23. https://doi.org/10.1007/s11104-014-2044-6

Temple, D.M., 1982. Flow Retardance of Submerged Grass Channel Linings. Trans. ASAE 25, 1300-1303. https://doi.org/10.13031/2013.33717

Temple, D.M., Robinson, K.M., Ahring, R.M., Davis, A.G., 1987. Stability Design of Grass-Lined Open Channels, Agriculture Handbook. U.S. Department of Agriculture, Washington, D.C.

Van Dijk, P.M., Kwaad, F.J.P.M., Klapwijk, M., 1996. Retention of water and sediment by grass strips. Hydrol. Process. 10, 1069-1080. https://doi.org/10.1002/(SICI)1099-1085(199608)10:8<1069::AIDHYP412>3.0.CO;2-4

Vannoppen, W., Vanmaercke, M., De Baets, S., Poesen, J., 2015. A review of the mechanical effects of plant roots on concentrated flow erosion rates. Earth-Sci. Rev. 150, 666-678. https://doi.org/10.1016/j.earscirev.2015.08.011

Vieira, D.A.N., Dabney, S.M., 2012. Two-dimensional flow patterns near contour grass hedges. Hydrol. Process. 26, 2225-2234. https://doi.org/10.1002/hyp.8262

Xiao, B., Wang, Q., Wang, H., Dai, Q., Wu, J., 2011. The effects of narrow grass hedges on soil and water loss on sloping lands with alfalfa (Medicago sativa L.) in Northern China. Geoderma. 167-168, 91-102. https://doi.org/10.1016/j.geoderma.2011.09.010

Yang, C.T., 1972. Unit stream power and sediment transport. ASCE J. Hydraul. Div. 98, 1805-1826.

Yuan, Y., Bingner, R.L., Locke, M.A., 2009. A Review of effectiveness of vegetative buffers on sediment trapping in agricultural areas. Ecohydrology 2, 321-336. https://doi.org/10.1002/eco.82

Zhu, H., Fu, B., Wang, S., Zhu, L., Zhang, L., Jiao, L., Wang, C., 2015. Reducing soil erosion by improving community functional diversity in semi-arid grasslands. J. Appl. Ecol. 52, 1063-1072. https://doi.org/10.1111/1365-2664.12442 